\title{
Patients' Perceptions of food Service Quality at Royal Prima Hospital Medan
}

\author{
Lidia Marianne Anggreni Simanjuntak ${ }^{1}$, Destanul Aulia ${ }^{2}$, Albiner Siagian $^{2}$ \\ ${ }^{1}$ Master Student in Universitas Sumatera Utara, Medan, Indonesia \\ ${ }^{2}$ Lecturer in Universitas Sumatera Utara, Medan, Indonesia \\ Email: lidia_marianne@yahoo.co.id
}

\begin{abstract}
:
This study deals with patients' perceptions of food service quality at Royal Prima Hospital Medan. Someone's perception in evaluating the quality of service will greatly affect customer satisfaction. From someone's perception, it will produce a sense of satisfaction or dissatisfaction with the service. And this will greatly affect the desire or willingness to use or use the service. This type of qualitative research will be used is a case study approach with in-depth interviews with informants. The case study approach focuses intensively on one particular object that studies it as a case. Based on HTA assessment that the patient's perception of nutritional service at Royal Prima Hospital is still in accordance with what is expected of the patient's wishes. It can be concluded that the method of serving food at the hospital is good in its implementation, where the waitress in serving food greets the patient by mentioning the patient's identity to adjust whether the diet given is right for the intended patient. Therefore, the assessment based on HTA has met the MOH standards.
\end{abstract}

Keywords:

Patients; food service; Royal Prima Hospital Medan

\section{Introduction}

Nutrition services in hospitals are part of health services in hospitals. Nutrition services program aims to improve the quality of hospital services through efforts to provide nutritional services that are efficient and successful and integrated with other health services in hospitals. The main activities of the hospital nutrition services include production / processing (procurement to distribution to patients), nutrition services in food treatment rooms (planning to diet evaluation), counseling.

The food service system in a hospital is a supporting part in health services which is part of medical therapy. During this time the food service in the hospital seemed to stand alone, even though in its operating system the food service system must work hand in hand with medical services and other service systems that operate in the hospital in order to provide optimal service to patients.

The services provided will be adjusted to the patient's condition based on clinical condition, nutritional condition, and metabolic status of the body. The nutritional state of the patient is very influential in the process of healing the disease. Conversely, the course of the disease can affect the patient's nutritional state and often the patient's condition worsens due to insufficient nutritional requirements for the improvement of bodily functions. The disrupted function of the organs of the body will worsen with disease and malnutrition.

Other nutritional services that are not less important are nutrition care services, which are the provision of food for patients in hospitals and are a very important factor in helping the healing process of the disease. If the patient gets proper nutrition during treatment at the 
hospital it can help the healing process, prevent complications, and reduce mortality.

This situation is supported by research conducted in Germany, which shows the same results. This situation is caused by the illness suffered by patients already in a critical phase, but also because of the internal condition of the patient and poor nutrition services. All factors are thought to contribute to the problem of malnutrition in hospitals. This is due to the management and doctors in the hospital who still continue to see that nutritional therapy is not part of disease therapy. Another contributing factor is the lack of capacity of the nutrition care team and food providers.

Nutrition problems in hospitals can also be assessed according to individual conditions that directly or indirectly affect the process healing. The tendency of increasing cases of nutritional-related diseases can attack all vulnerable groups in the hospital, both starting from pregnant women, infants, children, adolescents, to the elderly (the elderly). This problem requires special nutrition management. Therefore, quality nutrition services are needed to achieve and maintain optimal nutritional status and accelerate healing in hospitals.

\section{Review of Literature}

\subsection{Hospital Nutrition}

Nutrition service is one of the services performed in each hospital, based on hospital nutrition services guidelines namely the Ministry of Health (2013). Hospital nutrition services are part of the health services in hospitals. Nutrition services focus on the needs and satisfaction of patients in aspects of promotion, prevention, treatment and rehabilitation to improve quality of life. While the nutritional status of patients in hospitals greatly affects the cure rate in patients. If the patient's nutritional intake is not good it will affect hospital malnutrition (Kusumayanti, 2014). If malnutrition in the hospital is not good, it will affect many things, namely increased length of treatment, increased pain, delayed healing, and increased costs of care (Amatsier, 2009).

Ministry of Health Republic of Indonesia (2013) also revealed that nutrition care and provision of food for patients are nutritional services in hospitals and are a very important factor in helping the healing process of the disease. If the patient gets proper nutrition during treatment at the hospital it can help the healing process, prevent complications, reduce morbidity and mortality. Thus it can shorten the length of days of hospitalization and reduce the cost of treatment. Budiningsari RD (2004) stated that currently many patients undergoing hospitalization in Indonesian hospitals have decreased nutritional status to be malnourished, especially malnutrition. Research conducted in Germany (Wahyuni, S, 2005) shows the same thing. This condition is caused because the patient's illness is already in a critical phase, but also because of the patient's internal condition and inadequate nutrition services. The factors that contribute to the problem of malnutrition in hospitals are the management and hospital doctors who still view that nutritional therapy is not part of disease therapy, and other contributing factors are the lack of capacity of the nutrition care team and food providers.

\subsection{Supervision of Nutrition Services}

Supervision is one of the management functions that strives for work or activities to be carried out in accordance with the plan, and the policies set can achieve the desired goals. Supervision has a positive impact in the form of: 1) stopping or eliminating mistakes, deviations, deviations, waste, constraints and disorder; 2) prevent the recurrence of mistakes, deviations, deviations, waste, obstacles and disorder; 3) looking for better ways or fostering 
better ways to achieve goals and carry out organizational tasks.

Quality control and control is an activity in supervising and controlling quality to guarantee the expected results in accordance with standards. Supervision and control strategies in the form of monitoring and control through statistical processes or techniques to maintain the quality of products that have been predetermined. The methods that are often used in quality control and control are, assessing final quality, evaluating output, controlling quality, and monitoring daily activities.

Basically there are 4 steps that can be done in the supervision and control of service quality, namely: 1) preparation of standards, both cost standards, quality service standards, product safety quality standards, etc .; 2) conformity assessment, i.e. comparing products produced or services offered against these standards; 3) make corrections if necessary, by correcting the causes and factors that affect satisfaction; 4) quality improvement planning, which is building sustainable efforts to improve existing standards. Nutrition services in hospitals are said to be of quality if they meet 3 quality components, namely: 1) supervision and quality control to ensure that the products produced are safe; 2) guarantee customer satisfaction; 3) quality assessment.

\subsection{The Role of Hospital Management in Nutrition Services}

In every hospital, there will certainly be a role for nutrition service management, nutrition service management is very important to be able to produce quality food and can speed up the healing process of patients. The purpose of nutrition service management is to keep the nutritional installation always able to function properly, efficiently, economically, in accordance with its initial specifications or capabilities. And the functions of management are as follows:

Planning. Planning is one of the functions of health management that plays a role in systematically preparing activities to be carried out to achieve certain goals. Good planning requires an adequate monitoring and evaluation system and functioning feedback for control measures.

Organizing nutrition services. Organizing is a process of grouping people, tools, tasks, responsibilities or authority in such a way as to create an organization that can be mobilized in order to achieve the goals set. As a manager, the head of the nutrition installation must continue to carry out the management function properly by planning, organizing, directing, coordinating, overseeing the activities in the nutrition installation by improving overall quality and can increase satisfaction to other health workers and to the patient as a whole.

Implementation of nutrition services. Implementation is the implementation stage of the entire management chain. The implementation of nutrition services includes the provision of food, nutrition care activities, and diet therapy.

Supervision of nutrition services. Supervision is carried out with the aim that the implementation of activities in accordance with the plans and policies set, knowing as early as possible progress and irregularities that occur in implementation, and if there are irregularities and obtain new materials can be used for the preparation of further programs. 
Evaluation of nutrition services. Evaluation is carried out to find out whether the activities carried out have achieved their objectives or not. The purpose of the evaluation is to assess the implementation of activities in accordance with the plans and policies compiled so that they can achieve the desired goals.

\subsection{Patients' Perceptions of Service Quality}

The quality of a hospital's health services can be reflected in the patient's perception of the health services received and that perception will continue in the process of forming an image. Image has two principal components, namely functional and emotional. The functional component is related to tangible characteristics, which are easily measured, while the emotional component is associated with psychological dimensions that are associated with feelings and attitudes towards an organization (Ekayanti, 2013).

Someone's perception in evaluating the quality of service will greatly affect customer satisfaction. From someone's perception, it will produce a sense of satisfaction or dissatisfaction with the service. And this will greatly affect the desire or willingness to use or use the service. Consumers who are satisfied will be willing to reuse one day or repurchase the service product or will even declare or convey information about the product's superiority to others (Azizatul, 2016).

\subsection{Health Technology Assessment (HTA)}

According to Ministry of Health Republic of Indonesia (2017) health technology assessment (health technology assessment) is a process of systematic evaluation of the effects and other impacts of health technology. Besides HTA is a structured analysis of health technology that is used as input in policy making, including safety, efficacy (benefit), costs, and cost effectiveness. In Indonesia HTA is still new and not widely used. Health Technology is the techniques, drugs, tools and procedures used by the medical profession in providing medical services to a person and the system in which medical services are provided (US Office of Technology Assessment, 1982). Health technology can be in the form of an action, such as nutrition services in hospitals, medicine, and many others. The health services provided must pay attention to the principles of quality control and cost control, one of which is the HTA approach.

\section{Research Method}

This type of qualitative research will be used is a case study approach with in-depth interviews with informants. The case study approach focuses intensively on one particular object that studies it as a case. Case study data can be obtained from all parties concerned, in other words in this study collected from various sources. (Nawawi, 2003). In this case, hospital management, technology in nutrition services, patient's perceptions and views.

This research was conducted at the Royal Prima General Hospital (Type B). This location is a place of research because this hospital has implemented HTA (Health Technology Assessment).

\section{Discussion}

Food service quality in hospitals includes variations in food menus, ways of serving food, image of food taste, timeliness, serving food, food place conditions, food hygiene, attitude and behavior of serving staff, and monitoring of officers when eating. 


\section{a. Food Menu Variations}

Variations in the food menu is a variety of food menus provided. The more varied diet, can increase the level of appetite of patients in the hospital. The results of interviews with inpatients at Royal Prima General Hospital regarding variations in the food menu provided by the Nutrition Installation at Royal Prima General Hospital were obtained as follows:

"kalo variasi makanannya lumayanlah dek, ganti-ganti terus. Kayak misalnya pagi ini makan pake ikan digoreng, siangnya makan pake ayam, malamnya pake ikan digule" (P38L11-13).

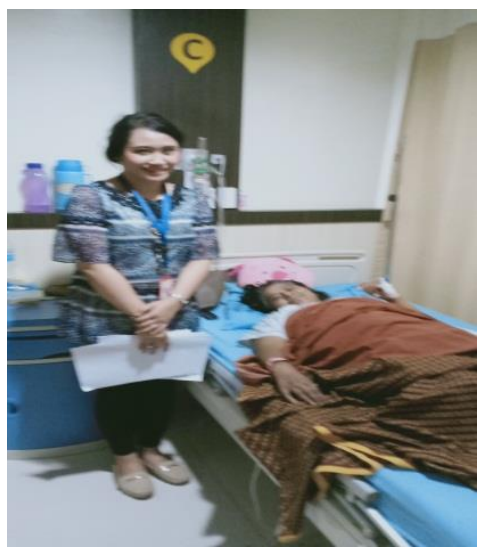

Figure 1. Interview with Ms. Ringga, class III inpatient at Royal Prima Hospital (Informant 1)

The results of interviews with inpatients at Royal Prima Hospital (Informant 1) regarding the variety of food menus provided by the Nutrition Installation at Royal Prima Hospital were obtained as follows:

"makanannya ganti-ganti nak. Saya suka di sini macam-macam menu makanannya dan lengkap. Kayak misalnya pagi kita dikasi bubur pake telor, dikasi buah dan teh manis hangat lagi. Sama juga kayak siang, dan malam juga kayak gitu. Ganti-ganti menu makanannya nak"(P40L11-15)

The results of interviews with inpatients at Royal Prima Hospital (Informant 1) regarding the variations on the menu provided by the Nutrition Installation at Royal Prima Hospital were obtained as follows:

"di rs ini makanannya enak dek. Makanannya ganti-ganti tiap hari" (P42L11-12)

Based on the results of interviews with inpatients at Royal Prima Hospital regarding variations in the food menu provided, it shows that the food menu provided varies with each food schedule. The themes obtained from the above research results are obtained as follows:

Table 1. Variations in food menus

\begin{tabular}{lc}
\hline \multicolumn{1}{c}{ Sub-Theme } & Theme \\
\hline 1. Variation of alternating food menus & Food menu variations \\
2. Variations in food menu consisting of breakfast, & \\
lunch, lunch, afternoon snack, and dinner & \\
\hline
\end{tabular}

\section{b. Food serving}

Food serving is a way to serve food to patients / guests to eat as a whole which contains a composition that is arranged and adjusted to the color game that is arranged in an attractive manner so as to increase appetite. The results of interviews with inpatients at Royal Prima Hospital (Informant 2) regarding the way food is served by the waiter is obtained: 
"petugas yang ngantar makanan bagus dek. Sopan, dan ramah. Kayak misalnya pagi-pagi ketuk pintu kamar dulu bilangnya: pagi, bu. Dengan ibu nama: minarsih, umur 54 tahun, kamar 504. Saya antar sarapan pagi ibu ya. Selamat makan bu. Gitu dek bilangnya" (P38L16-20)

The results of interviews with inpatients at Royal Prima Hospital regarding the way food is served by the waitress is obtained as follows:

"penyajian makanannya bagus nak. Asal petugasnya mau masuk kamar, diketok pintu dulu, disapa kita, dan disajikan makanan di atas meja" (P40L18-20)

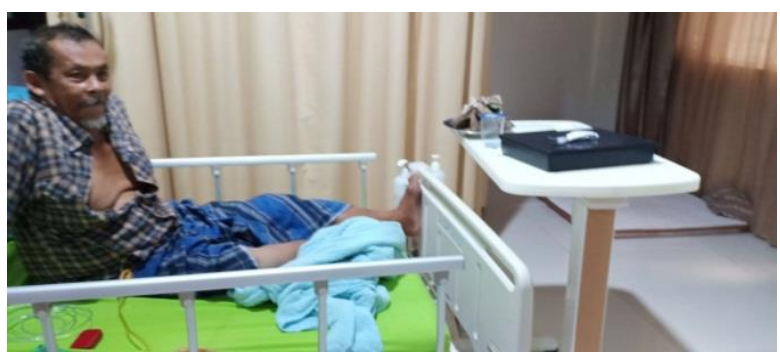

Figure 2. Interview with Mr. Ramlan, class III inpatient at Royal Prima Hospital (Informant 2)

The results of interviews with inpatients at Royal Prima Hospital (Informant 2) regarding the way food is served by the waiter is obtained as follows:

"yang menyajikan makanan bagus dek. Petugasnya ramah" (P42L16-17)

Based on the results of interviews with inpatients at Royal Prima Hospital regarding the way food is served by the waiter shows that the way the food is served in the hospital is good in its implementation, where the waitress in serving food greets the patient by mentioning the patient's identity to adjust whether the diet provided it is appropriate for the intended patient. The themes obtained from the above research results are obtained as follows:

Table 2. Food serving

\begin{tabular}{ll}
\hline \multicolumn{1}{c}{ Sub-Theme } & Theme \\
\hline $\begin{array}{l}\text { 1. Serve food with polite and friendly attitude from the clerk } \\
\text { 2. Food presentation has been done well }\end{array}$ & Food serving \\
\hline
\end{tabular}

\section{c. The Taste of Food}

The taste of Food is caused by the stimulation of various senses in the human body, especially the sense of sight, the sense of smell, and the sense of taste. Foods that have a high taste are foods that are served attractively, spread a pleasant odor, and provide a delicious taste. The results of interviews with inpatients at Royal Prima Hospital (Informant 3) regarding the image of food taste were obtained as follows:

"kalo makanannya dek, rasanya lumayanlah, nasinya ga keras, ikan, dan sayurnya juga

baru dimasak, dan biasanya masih hangat pas dikasi" (P39L23-25)

The results of interviews with inpatients at Royal Prima Hospital (Informant 3) regarding the image of food taste were obtained as follows:

"yah tau sendirilah nak, makanan di RS kayak mana. Yang penting bisa dimakan aja nak" (P41L23-24) 
The results of interviews with inpatients at Royal Prima General Hospital (Informant 3) regarding the image of food taste were obtained as follows:

"rasa makanannya enak dek. Yang dikasi pas lagi hangat-hangatnya. Ada dikasi buah juga. Lengkaplah" (P42L18-19)

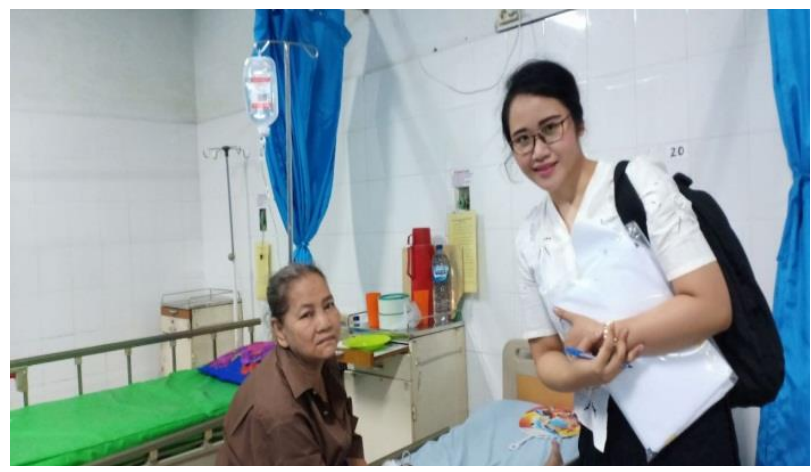

Figure 3. Interview with Ms. Tiurjana, class III inpatient Dr. Pirngadi Hospital (Informant 3)

Based on the results of interviews with inpatients at Royal Prima Hospital regarding food imagery served, it shows that the image of taste, aroma, texture, temperature, and taste of food is still in good judgment from patients. The themes obtained from the above research results are obtained as follows:

Table 3. The Taste of Food

\begin{tabular}{l}
\hline Sub-Theme \\
\hline 1. The Taste of Food that is the food served is \\
interesting, delicious smell and delicious taste \\
2. The Taste of Food is sometimes in accordance \\
with the wishes of the patient and sometimes not \\
in accordance with the wishes of the patient
\end{tabular}

\section{d. Timely Serving Food}

Timeliness in serving food is the serving of food to patients on time in accordance with a predetermined food schedule. The results of interviews with inpatients at Royal Prima Hospital (Informant 4) regarding the timeliness in serving food were obtained as follows:

"makanan yang disajikan selalu tepat waktu dek, sejauh ini sih kayaknya ga pernah telat. Contohnya jadwal sarapan jam 06.00 pagi, nanti petugasnya udah dtg jam 05.45 sekitar jam segitulah" (P39L28-30)

The results of interviews with inpatients at Royal Prima Hospital (Informant 4) regarding the timeliness in serving food were obtained as follows:

"jadwal makan datang ke kamar kita selalu tepat nak, malah kadang petugas lebih cepat datang dari jadwal yang ada. Kayak pagi kan biasanya makan jam 06.00, eh mereka udah datang ngantar makanan jam 05.30" (P41L27-30)

The results of interviews with inpatients at Royal Prima Hospital (Informant 4) regarding the timeliness in serving food were obtained as follows:

"Tepat koq dek. Ga pernah terlambat datang makanannya" (P42L22)

Based on the results of interviews with inpatients at Royal Prima Hospital regarding the timeliness in serving food shows that the staff in serving food is always on time. 
Results of interviews with inpatients at RSU Dr. Pirngadi (Informant 4) regarding timeliness in serving food was obtained as follows:

"biasanya sih dek. Kadang tepat waktu, kadang lewat 5 atau 10 menit gitu. Kayak kita jadwal makan paginya jam 06.00 pagi, diantar sama kita jam 06.05 atau jam 06.10" (P80L25-27)

Results of interviews with inpatients at Dr. Pirngadi Hospital (Informant 4) about the timeliness in serving the food obtained as follows:

"selalu tepat waktu nak. Kalaupun telat-telat dikit itu 10 atau 15 menitlah. Misalnya kita makan siang jam 12, diantar jam 12.15 sekitaran segitulah" (P82L25-27)

Results of interviews with inpatients at Dr. Pirngadi Hospital (Informant 4) about the timeliness in serving the food obtained as follows:

"yah jam makanannya tepat waktu dek. Jarang sih kalau telat. Itupun kalau telat lewat 10 atau 15 menitlah dek"(P84L27-28)

Based on the results of interviews with inpatients at Dr. Pirngadi Hospital about the timeliness in serving food regarding the officers in serving food that was not on time. Themes derived from the results of the research are obtained from the following:

Table 4. Timely of Serving Food

\begin{tabular}{|c|c|}
\hline Sub-Theme & Theme \\
\hline $\begin{array}{l}\text { 1. Timely serving of food has been implemented } \\
\text { 2. Timely serving of food is in accordance with } \\
\text { a predetermined schedule }\end{array}$ & Timely serving food \\
\hline
\end{tabular}

\section{e. Food situation and Food Hygiene}

The condition of the food container is the physical condition of the food place that meets the established standards and the hygienic location of the patient's food served. Food hygiene is hygienic food that has been processed and will be served to patients. The results of interviews with inpatients at Royal Prima Hospital (Informant 5) regarding the condition of the place of food and food hygiene served to patients were obtained as follows:

"yah tempat makanannya lumayanlah dek, dan makanan yang dikasi bersih koq" (P39L3233)

The results of interviews with inpatients at Royal Prima Hospital (Informant 5) regarding the condition of the place of food and food hygiene served to patients were obtained as follows:

"kalo tempat makannya bagus nak. Makanan yang disajikan juga bersih" (P41L32-33)

The results of interviews with inpatients at Royal Prima Hospital (Informant 5) regarding the state of the food and the cleanliness of the food served to patients were obtained as follows:

"tempat makannya bagus dek. Makanannya juga bersih" (P43L24)

Based on the results of interviews with inpatients at Royal Prima Hospital regarding the condition of the place of food and the cleanliness of the food served to patients' shows that the condition of the place is good and the cleanliness of the food served is clean. 
Results of interviews with inpatients at Dr. Pirngadi Hospital (Informant 5) regarding the condition of the place of food and the cleanliness of the food served to patients was obtained as follows:

"sejauh ini tempat makannya standarlah dek. Makanannya bersih juga dek" (P80L29-30)

Results of interviews with inpatients at Dr. Pirngadi Hospital (Informant 5) regarding the state of the place of food and the cleanliness of the food served to patients was obtained as follows:

"makanannya bersih nak. Tempat makanannya lumayan bagus juga nak" (P82L29-30)

Results of interviews with inpatients at Dr. Pirngadi Hospital (Informant 5) regarding the condition of the place of food and the cleanliness of the food served to patients was obtained as follows:

"tempat makannya biasa aja dek. Makanannya bersih" (P84L30)

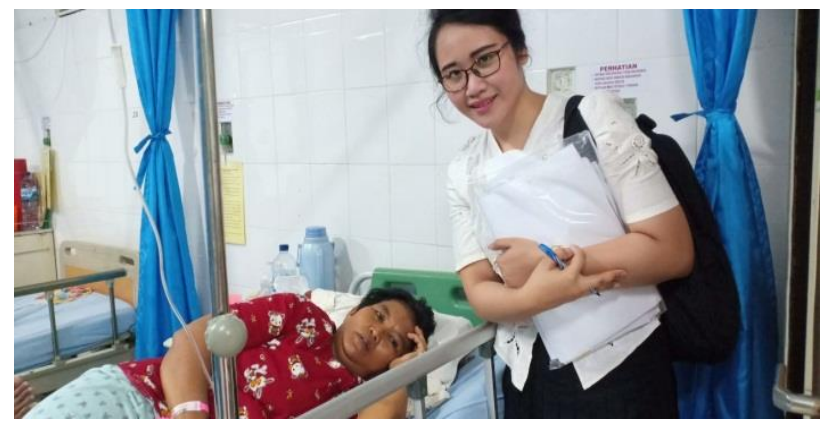

Figure 4. Interview with Ms. Minarsih, inpatient in class III Dr. Pirngadi Hospital (Informant 6)

Based on the results of interviews with inpatients Dr. Pirngadi Hospital regarding the state of the place of food and the cleanliness of the food served to patients shows that the state of the place of food is good and the cleanliness of the food served is clean. The themes obtained from the above research results are obtained as follows:

Table 5. The Condition of Food Place and Food Hygiene

\begin{tabular}{lll}
\hline \multicolumn{1}{c}{ Sub-Theme } & \multicolumn{1}{c}{ Theme } \\
\hline 1. & Clean food place & Food preparation and \\
2. & Food hygiene that is as expected & processing \\
\hline
\end{tabular}

\section{f. The Attitude, Behavior and Neatness of the Officers in Serving Food}

The attitude and behavior of officers in serving food is the attitude and behavior that is polite and friendly in serving food to patients. The results of interviews with inpatients at Royal Prima General Hospital (Informant 7) regarding the attitudes, behavior, and neatness of the officers in serving food were obtained as follows:

"petugasnya sopan, ramah, dan rapi dek" (P39L36)

The results of interviews with inpatients at Royal Prima Hospital (Informant 8) regarding the attitudes, behavior, and neatness of the officers in serving food were obtained as follows:

"sikap petugas sama kita sopan dan ramah nak. Rapi juga pakaiannya" (P41L36-37)

The results of interviews with inpatients at Royal Prima Hospital (Informant 9) regarding the attitudes, behavior, and neatness of the staff in serving food were obtained:

"sopan koq dek. Pakaiannya juga rapi" (P43L27) 
Based on the results of interviews with inpatients at Royal Prima Hospital regarding the attitude and behavior of officers in serving food shows that the attitudes and behavior of officers are polite and friendly, and neat when carrying out their duties.

Results of interviews with inpatients at RSU Dr. Pirngadi (Informant 10) regarding the attitudes, behavior, and neatness of officers in serving food obtained as follows:

"petugas yang nyajikan makanan sopan dek. Pakaiannya juga rapi" (P80L33-34)

Results of interviews with inpatients at Royal Prima Hospital (Informant 11) regarding the attitudes, behavior, and neatness of officers in serving food obtained as follows:

"sopan nak. Kalau pakaiannya rapi juga nak" (P82L33)

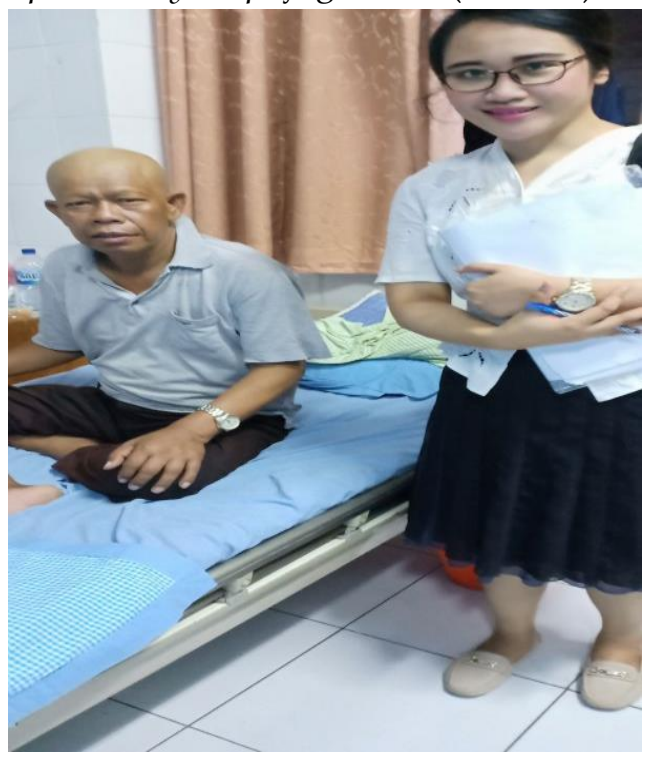

Figure 5. Interview with Mr. Nikson Limbong, class III inpatient Dr. Pirngadi (Informant 12)

Results of interviews with inpatients at RSU Dr. Pirngadi (Informant 12) regarding the attitudes, behavior, and neatness of officers in serving food obtained as follows:

"sejauh ini sopan dan ramah dek. Pakaiannya juga rapi dek" (P84L33)

Based on the results of interviews with inpatients Dr. Pirngadi's attitude and behavior in serving food shows that the officers' attitudes and behavior are polite, friendly, and neat when carrying out their duties. The themes obtained from the above research results are obtained as follows:

Table 6. Attitudes, behavior, and neatness of officers in serving food

\begin{tabular}{|c|c|}
\hline $\begin{array}{l}\text { Sub Theme } \\
\end{array}$ & Theme \\
\hline $\begin{array}{l}\text { 1. The attitude and behavior of the officers are } \\
\text { friendly and polite in serving food } \\
\text { The neatness of the officers who are already } \\
\text { good in serving food }\end{array}$ & $\begin{array}{l}\text { The attitude, behavior and } \\
\text { neatness of the officers in } \\
\text { serving food }\end{array}$ \\
\hline
\end{tabular}

\section{g. Monitoring officer}

Monitoring officer to patients when eating is a monitoring, if there is no match of the food served both in terms of the state of the food, the image of food taste, food hygiene. The results of interviews with inpatients at Royal Prima Hospital (Informant 13) regarding the monitoring of officers when patients eat were obtained as follows: 
"kayaknya ga ada dek. Ga ada petugas yang mantau kita di ruangan" (P39L38-39)

The results of interviews with inpatients at Royal Prima Hospital (Informant 13) regarding the monitoring of officers when patients eat were obtained as follows:

"ga ada sepertinya nak. Yah kalaupun ada makanan yang ga cocok sama kita, kita kasi tau sama petugas yang baru nyajikan" (P41L39-40)

The results of interviews with inpatients at Royal Prima Hospital (Informant 14) regarding the monitoring of officers when patients eat were obtained as follows:

"petugasnya ga ada yg mantau kita selama kita makan dek" (P43L29)

Based on the results of interviews with inpatients at Royal Prima Hospital regarding the monitoring of officers when patients eat shows that there are no officers who monitor patients while eating. Results of interviews with inpatients at RSU Dr. Pirngadi (Informant 15) regarding the monitoring of officers when patients eat is obtained as follows:

sepertinya tidak ada petugas yang monitor kita selama makan dek" (P80L36-37)

Results of interviews with inpatients at RSU Dr. Pirngadi (Informant 15) regarding the monitoring of officers when patients eat is obtained as follows:

"tidak ada nak saya lihat" (P82L34-35)

Results of interviews with inpatients at RSU Dr. Pirngadi (Informant 16) regarding the monitoring of officers when the patient ate was obtained as follows:

"petugas yang monitor kita selama makan kayaknya ga ada lah dek" (P84L35-36)

Based on the results of interviews with inpatients Dr. Pirngadi regarding the monitoring of officers when the patient was eating showed that there were no officers who monitored the patients while eating. The themes obtained from the above research results are obtained as follows:

Table 7. Monitoring of officers

Sub Theme Theme

1. There is no monitoring of officers when patients eat Monitoring officer

Assessment of patient perception based on HTA assessment of nutrition services at Royal Prima and Dr. Pirngadi Hospital can be described through the following table:

Table 8. Patients' Perception of Nutrition Services

\begin{tabular}{|c|c|c|c|c|c|}
\hline \multirow[t]{2}{*}{ No } & \multirow[t]{2}{*}{ Precondition } & \multicolumn{2}{|c|}{ Information } & \multicolumn{2}{|c|}{ Assessment HTA } \\
\hline & & RSURP & RSUP & RSURP & RSUP \\
\hline 1 & Food menu variations & $\sqrt{ }$ & $\sqrt{ }$ & $\sqrt{ }$ & $\sqrt{ }$ \\
\hline 2 & Food serving & $\sqrt{ }$ & $\sqrt{ }$ & $\sqrt{ }$ & $\sqrt{ }$ \\
\hline 3 & Image of the taste of food & $\sqrt{ }$ & $\sqrt{ }$ & $\sqrt{ }$ & $\sqrt{ }$ \\
\hline 4 & Timely serving food & $\sqrt{ }$ & $\sqrt{ }$ & $\sqrt{ }$ & $\sqrt{ }$ \\
\hline 5 & $\begin{array}{l}\text { Food situation and food } \\
\text { hygiene }\end{array}$ & $\sqrt{ }$ & $\sqrt{ }$ & $\sqrt{ }$ & $\sqrt{ }$ \\
\hline 6 & $\begin{array}{l}\text { Attitude, behavior, and } \\
\text { neatness of officers }\end{array}$ & $\sqrt{ }$ & $\sqrt{ }$ & $\sqrt{ }$ & $\sqrt{ }$ \\
\hline 7 & Monitoring officers & $\sqrt{ }$ & $\sqrt{ }$ & $\sqrt{ }$ & $\sqrt{ }$ \\
\hline
\end{tabular}

Source: Primary Data (Interview Results) 
From table 8 it is known based on HTA assessment that the patient's perception of nutritional service at Royal Prima and Dr. Pirngadi Hospital is still in accordance with what is expected of the patient's wishes.

\section{Conclusion}

The quality of food services in hospitals includes variations in food menus, ways of serving food, image of food taste, timeliness, serving food, food place conditions, food hygiene, attitude and behavior of serving officers, and monitoring of officers when eating.

Inpatients at Royal Prima Hospital regarding the variety of food menus provided show that the food menu provided varies with each available food schedule so that the assessment based on HTA meets Ministry of Health standards. The way food is served by the waitress at Royal Prima Hospital shows that the method of serving food at the hospital is good in its implementation, where the waitress in serving food greets the patient by mentioning the patient's identity to adjust whether the diet given is right for the intended patient. Therefore, the assessment based on HTA has met the MOH standards. Image of the taste of food served at Royal Prima General Hospital shows that the image of taste, aroma, texture, temperature, and taste of the food is still in a good assessment from the patient so that the assessment based on HTA meets the MOH standards. Timeliness in serving food at Royal Prima Hospital shows that officers in serving food are always on time so that the assessment based on HTA meets Ministry of Health standards. The condition of the food place and food hygiene at Royal Prima Hospital served to patients shows that the condition of the food place is good and the cleanliness of the food served is clean so that the assessment based on HTA meets Ministry of Health standards. The attitude and behavior of officers in serving food at Royal Prima Hospital shows that the attitude and behavior of officers is polite and friendly, and neat when carrying out their duties so that the assessment based on HTA meets Ministry of Health standards. Monitoring of officers at Royal Prima Hospital when patients are eating shows that there are no officers who monitor patients while eating so that assessments based on HTA meet Ministry of Health standards.

\section{References}

Aula E. (2011). Faktor-Faktor Yang Berhubungan Dengan Sisa Makanan Pada Pasien Rawat Inap Di Rumah Sakit Haji. Jakarta.

Almatsier, S. (2004).Penuntun Diit edisi baru, Jakarta GramediaPustakaUtama.

Almatsier, S (2009). Prinsip Dasar Ilmu Gizi . Jakarta: Gramedia Pustaka Utama.

Al-Assaf, A.F. (2012). Mutu Dalam Layanan Kesehatan : Perspektif Internasional. Jakarta : Penerbit Buku Kedokteran EGC.

Arifuddin, $M$ in Zakiyah. (2007). Analisis Sisa Makanan Lunak Rumah Sakit Pada Penyelenggaraan Makanan Dengan Sistem Outsourching di RSUD Gunung Jati Kota Cirebon. Tesis: Universitas Gajah Mada.

Barker et. Al. (2011). Hospital Malnutrition Prevalence, Identification, And Inpact On Patients Health Care System Int. J. Erviron Res: Publick Health

Benard, H. Russell (2006). Research Methods In Anthropology: Qualitative And Quantitative Approaches, UK: Altamira Press.

Budiningsari RD, Hadi H. (2006). Pengaruh perubahan status gizi pasien dewasa terhadap lama rawat inap dan biaya rumah sakit. Jurnal Gizi Klinik Indonesia.

Bungin, Burhan. (2009). Analisis Penelitian Data Kualitatif. Jakarta: Raja Grafindo.

Démuth, Andrej. 2013. Perception Theories. Faculty of Philosophy and Arts Tranava 
University in Tranava.

Denzin, Norman, K, et al. (2005). Handbook Of Qualitative Research. Jogyakarta: Pustaka Pelajar.

Direktorat Jenderal Bina Kesehatan Masyarakat. (2006). Pedoman Pelayanan Gizi Rumah Sakit. Jakarta: Direktorat Jenderal Bina Kesehatan Masyarakat, Departemen Kesehatan RI.

Direktorat Jenderal Bina Kesehatan Masyarakat. (2007). Pedoman Penyelenggaraan Makanan Rumah Sakit. Jakarta: Direktorat Jenderal Bina Kesehatan Masyarakat, Departemen Kesehatan RI.

Divianto. (2014). Pengaruh Kualitas Layanan Terhadap Kepuasan Pasien Medical Check Up (MCU) Pada Rumah Sakit Dr. Ak. Gani Palembang. Jurnal : Orasi Bisnis Edisi ke-XI, Mei 2014. ISSN: 2085-13.

Gordon, L.A. (2004) . Management Accounting System, Perceived Environmental Uncertainty and Organization Structure : An Empirical Investigation, Accounting, Organizational and Society. Vol. 9 No. 1. Pp. 33-47.

Hamidiyah. A, (2013). Hubungan Persepsi Pasien Tentang Kualitas Pelayanan

Dengan Minat Kunjungan Ulang Di Klinik Umum Rumah Sakit Bhineka Bakti Husada Kota Tangerang Selatan.

Nida,K., (2011), Faktor-faktor Yang Berhubungan Dengan Sisa Makanan Pasien Rawat Inap Di Rumah Sakit Jiwa Sambang Lihum. Banjarmasin.

Pohan I.S. 2004.Jaminan Mutu Layanan Kesehatan: Dasar-dasar Pengertian dan Penerapan. Jakarta: Penerbit Buku Kedokteran EGC.

Rahmulyono, A. (2008). Analisis Pengaruh Kualitas Pelayanan Terhadap Kepuasan Pasien. Depok I Sleman

Reksohadiprodjo, et al. (1999). Organisasi Perusahaan Teori,Struktur Dan Perilaku, Yogyakarta, BPFE

Tjiptono, Fandy. (2010). Pemasaran Strategik, Penerbit Andi, Yogyakarta.

Undang-undang Republik Indonesia Nomor 36 Tahun 2009. Tentang Kesehatan (Lembaran Negara Republik Indonesia Tahun 2009 Nomor 144)

Undang-undang Republik Indonesia Nomor 44 Taahanun 2009. Tentang Rumah Sakit (Lembaran Negara Republik Indonesia Tahun 2009 Nomor 153)

Usman, H. (2014). Manajemen: Teori, Praktik Dan Riset Pendidikan, Jakarta: Bumi Aksara.

Valerie Z, Leonerd B, Parasuraman. (2010). Delivering quality service, balancing custumer perceptions and expantations. New York: The Freepress; Tjiptono, Fandy. Pemasaran Strategik, Penerbit Andi, Yogyakarta.

Wursanto, Drs. Ig. (2003). Dasar-Dasar Ilmu Organisasi, Yogyakarta.

Wahyuni S, et al. (2005). Budiningsari RD. Pengukuran status gizi pasien anak menggunakan metode Subjective Global Nutrition Assessment (SGNA) sebagai prediktor lama rawat inap, status pulang dan kejadian malnutrisi di rumah sakit: Jurnal Gizi Klinik Indonesia.

Zakiyah, Lili. (2005) Plate waste among hospital Inpatients,Malaysian Journal Of Puplic Health Medicine (Volume 5, no 2, 2005, Pages 19 to 24), University Of Malaya, Malaysia. 